\title{
Cross-Cultural Management and Organizational Performance: A Content Analysis Perspective
}

\author{
Mast Afrin Sultana ${ }^{1}$, Md. Mamunur Rashid ${ }^{2}$, Muhammad Mohiuddin ${ }^{2} \&$ Mohammad Nurul Huda Mazumder $^{2}$ \\ ${ }^{1}$ The Brain Technology Ltd., Dhaka, Bangladesh \\ ${ }^{2}$ Faculty of Administrative Sciences, Laval University, Canada \\ Correspondence: Muhammad Mohiuddin, Faculty of Administrative Sciences, Laval University, Canada. Tel: \\ 1-418-264-7798. E-mail: Muhammad.mohiuddin.1@ulaval.ca
}

\author{
Received: January 2, 2013 Accepted: March 20, 2013 Online Published: March 26, 2013 \\ doi:10.5539/ijbm.v8n8p133 URL: http://dx.doi.org/10.5539/ijbm.v8n8p133
}

\begin{abstract}
Globalization, offshore outsourcing, global value chain and global division of labor have led today's Business firms to internationalize their activities, therefore, cultural diversity become an important issue in managing the contemporary worldwide workplaces. In fact, it has become a necessity for managers to take this challenge by fully utilizing the potential capabilities of multi-cultural workforce in order to achieve organizational effectiveness. To address this situation, we attempted to understand the impact of cross-cultural diversity management on organizational effectiveness and competitive advantage in an organization. A content analysis method has been used in this article to explain the impact of cultural diversity management in order to accelerate firms' competitiveness. The outcome of our research indicates a significant and positive correlation of an effective cultural diversity management practices on competitive advantages and organizational effectiveness.
\end{abstract}

Keywords: cross-cultural management, competitive advantage, organizational effectiveness, content analysis

\section{Introduction}

Demographic changes led policy makers to adopt new strategies to meet the new challenges in the labor markets and this phenomenon is observed in the developed as well as in the labor shortaged emerging countries such as Malaysia or in the GCC (Gulf cooperation council) countires. This also facilitates the access to employment of visible minorities (Bassin, 1988; Levine, 1987; Raudsepp, 1988 \& White, 1999). In this context, few countries have implemented a policy of diversification by inviting workers from different cultural backgrounds by introducing equity policy regardless of race, religion and color in employment opportunities. Therefore, the labor markets of most developed as well as comparatively dynamic emerging countries are becoming increasingly multicultural and multiethnic. A strategic response to these changes is to manage this diversity by focusing on efficient use of all workers capabilities (Thornhill, Lewis, Millmore, \& Saunders, 2000) regardless of cultural backgrounds. Performance factors in terms of Moral, legal and economic values become the types of organizational goals that can be achieved by managing diversity (Cox, 1993). In these circumstances, many companies have developed and implemented a set of strategies for managing diversity in order to be more efficient and competitive in the global marketplace as well as in multi-cultural markets in manpower importing countries. Cultural management issue is a very much related topic of sociology or political science field. The managerial implication of cross-cultural management appeared to be an ensuing challenge for global firms when they are extending their businesses as a result of rapid pace of globalization (He \& Liu, 2010). But recent increases in low-cost labor and accelerated professional mobility have increased the room for debate on the impact of cultural diversity in workplace, which led researchers to study and advance their research in the field of cultural diversity. Despite this irreversible trend, only recently have researchers begun to seriously study the diversity management at firm level (Cox \& Beale, 1997). This growing interest in the management of cultural diversity research is due to the concurrent organizational challenges. Yingying Joaquín (2012) asserted that although the definition and concept of culture differs and the term are utilized in diverse occasions and circumstances with considerable diversity, it has become one of the most critical and relevant issues in the globalizing business world.Therefore, it has become a necessity for managers to understand the depth of the cultural diversity and to be able to implement strategies to fit individual identities within the collective group to ensure a harmonious relationship in organizational framework to achieve the organizational goal. Moreover, 
managers need to implement management systems that can lead cultural diversity to contribute effectively to the competitiveness of the company. In the literature, the most common attributes of this competitiveness consists of five key factors commonly called the 5C; human Capital, innovation Capital, organizational Capital, customer Capital and reputational Capital. Currently, general trend is to study the effect of cultural diversity management $(\mathrm{CDM})$ on organizational performance.

Our goal in this research, in particular, is to undertake a content analysis of a number of scientific articles in order to understand, qualitatively, the impact of the management of cultural diversity on competitive advantage of the company. Thus, our approach is to analyze a sample of thirty scientific papers dealing with the management of cultural diversity and the competitive advantage of companies. These are mainly the work of Leung, Maddux, Galinsky, and Chi-yue (2008); Dass and Parker (1993); Polzer et al. (2000); Chasserio and Legault (2009); Loth (2006); Palich and Gomez-Mejia (1999); Akinola and Thomas (2006); Seymen (2006), Mohiuddin, Mbibi, Al-Azad, and Diouf (2009), Cox and Blake (1991) and so on published between 1991 till 2009 in the leading management journals such as Journal of International Business Studies, Academy of Management Review, Strategic Management Journals, Cross Cultural Management Journal, Global Journal of Business Administration etc. The remaining of this paper is organized as follows: before presenting research methodology and data analysis (section 3), a review of literature on cultural diversity and its relationship with competitive advantage (section 2) followed by the conclusion and identifying the future research are addressed.

\section{Literature Review}

The concept of "cultural diversity" is both specific and contextual. Cultural diversity plays a critical role in organizations at the international context (Reddy, 2011) which has become a pivotal topic of concern among managers, researchers, and policy makers. Many contemporary researchers consider cultural diversity as an important difference distinguishing one individual from another, a description that covers a wide range of obvious qualities and hidden capabilities (Ivancevich \& Gilbert, 2000; Nkomo \& Cox, 1996). To understand the importance of managing cultural diversity, it seems important to grasp the concept of culture. According to Adler (1994), culture is an acquired behavioral aspect assigned to a person and his group by which the individual is identified, expressed and transmitted through symbols, distinguishing mark, its values and beliefs. Among the attributes, such as backgrounds, experiences, values and beliefs about each culture, the latter determines the perception of an individual's behavior, his ideas, and his way of thinking (Laine, 2004 in Côté, 2006). Culture, in its broader meanings, includes a rich set of principles and perceptions which, once expressed, can be juxtaposed with those from a different culture and creates confrontations for constructive learning.

Organizations that cultivate the virtues of diversity are predisposed to better integrate the global dynamics of the labor market dominated by increasingly multiethnic and multicultural force of that market (Jain \& Verma, 1996). Managing the diversity of the workforce has become an important issue for both governments and private entrepreneurs for public and private organizations. Its importance has increased mainly as a result of relative liberalization of labor market due to globalization, the development of migration and the fight for human rights carried out by certain minority groups who feel excluded from equitable job market.

The concept of "managing diversity in the workforce" has recently emerged mainly due to fulfillment of the approach of "equal opportunities" for all. The proactive strategy tends to gradually replace the reactive approaches. It is increasingly accepted that the heterogeneity provided by the cultural diversity can be an engine of growth for the efficiency of the organization in this competitive world (Nkomo \& Cox, 1996; Jackson \& Ruderman, 1995). Organizations that promote diversity within them and are deemed by their diversity management are likely to attract the best talented staff (Carrel \& Everett, 1995). Diversity in this sense is seen as a systematic and planned commitment of organizations to recruit, retain, reward, and promote a heterogeneous mix of employees (Gilbert, Stead, \& Ivancevich, 1999).

In concrete terms, cultural diversity in the workplace, exercised through the coexistence of workers from different backgrounds. Management of cultural diversity requires, therefore, a type of organizational culture in which every employee can continue his career unimpeded by gender, race, nationality, religion, or other factors which are not relevant to performance (Bryan, 1999). It, therefore, requires establishing the means for diverse workforce to be fully integrated in an equitable workplace where no group is privileged over another (Torres \& Brussels, 1992). The issue of cultural diversity is debated not only in business world but also increasingly, becoming the cornerstone of discussions in political circles and justice (Williams \& O'Reilly, 1998). As a result, agency managers have to understand, predict and manage the fascinating nature of the diverse workforce.

Management of cultural diversity is often related to competitive advantage. Numerous studies have helped to show that it can create competitive advantage for a company. The potential benefits of managing cultural 
diversity include better decision making, greater creativity and innovation, greater success in international marketing activities and with local minority ethnic communities, a better distribution of economic opportunities (Cox, 1991; Cox \& Blake, 1991). In the long term, according to Watson, Kannales, and Michaelsen (1993), compared to homogeneous groups, culturally diverse groups are more effective both in social interactions at the level of job performance. At the empirical level, according to Taylor (1995), a number of large companies in Canada, such as Petro-Canada, Bank of Montreal and Mouvement des Caisses Desjardins, recognized the positive contribution of cultural diversity to promote competitive advantage in their businesses.

The model created by Hofstede in 1970 became a cornerstone for cross-cultural research, providing an extremely popular method for the study of cultural differences in a wide range of disciplines, including international management (Michael \& Hofstede, 2011). It seems that it is already an established phenomenon pointing the robustness of cross-cultural literature. However, many researchers are still debating the theoretical perspectives that exert the benefits of cultural diversity (Palich \& Gomez-Mejia, 1999) by highlighting, among others, that diversity can create dissatisfaction and a decline in business performance (Milliken \& Martins, 1996). Others, more moderate, having emerged in context of globalization, but classic studies (Hall, 1959 \&1960, Lawrence \& Lorch, 1967; Hofstede, 1980) posited that the cultural diversity management of an organization provides benefits if and only if, it's well managed. According to Philip Iribane (1998), it is to establish a good mix between the different cultures in a business because every gesture, every word is an axiom that can not be challenged and we must put them in a cultural context. If the cultural diversity is mis-managed, it can be the source of negative impact because many people would feel threatened by working with people of diferent age, sex or cultural backgrounds. Therefore, this in-security can have a negative impact on overall productivity. Therefore, it is essential for a manager to identify the cultural specificity of a group to understand the way to react and solve the problems it faces (Trompenaars, 1993).

Encouraging diversity in organizations may stimulate creativity; improve the representativeness and access to the distinctive capabilities of minorities in an era of accelerating aging population in the developed countries. This will also ensure equity in employment/affirmative action and contribute to the human rights of the visible minorities in the country. A multicultural workforce with its collective intelligence and knowledge can produce higher quality goods to meet customer needs more satisfactorily. A multicultural work environment contributes to internal team work by transforming the workplace into a place of learning, practice of new ideas and behavioral testing and application of new rules and organizational processes for greater competitive advantage of the company. For example, people of color in the United States as a group today buy goods and services more than some of their international trading partners. Cox and Blake (1991) indicate that minorities prefer to work for an employer that values diversity as well as to buy goods and services from such companies.

This literature review has allowed us to highlight the importance of managing cultural diversity to enjoy all the skills of the workforce in order to create firm level competitive advantage. But to the best of our knowledge, none of these studies is based on a qualitative content analysis of previous work that shows the relationship between the management of cultural diversity, organizational effectiveness and competitive advantage. In the following section, we shall be describing the methodology used to answer our research question and then shall be proceding with data analysis. This research question is to ask, from the existing literature, if the management of cultural diversity has an impact on the competitive advantage of the company.

\section{Research Methodology and Data Analysis}

Qualitative approaches of data analysis advocates to develop the interpretative aspects and categories as close as possible to the object of the study (Van Dijk, 1977). In this context, the purpose of content analysis is "to provide knowledge and understanding of the phenomenon" (Downe-Wamboldt 1992). For Hsieh and Shannon (2005), a qualitative content analysis is a method of research for subjective interpretation of the contents of text through a process of systematic classification of coding and identification of themes or patterns. Note that the content analysis is a method of grounded theory analysis. From this general principle, each researcher, as part of our research, conducted a content analysis of a sample of ten articles. The analyzed texts were selected based on the following criteria: (i) Articles should address the management of cultural diversity and competitive advantage, (ii) the articles must be scientific (iii) the article must be published or pending approval for publication in a peer reviewed journal. The selection of articles has been decided by agreement among researchers. Once the articles have been selected, each researcher conducted the coding of the data by identifying the nodes and free nodes hierarchically.

The categories we have considered represent the dimensions of cultural diversity and those that can boost the competitiveness of a company. It seems important to mention that the codification process of 'free nodes', has 
been guided by our research questions. One of the researchers conducted deductive coding and the other two carried out inductive coding process. The categories identified independently by each researcher are very close semantically, but one of the researchers identified a number of categories higher than the other two. Some concepts are semantically identical or similar code top level for a researcher as they are second-level codes for another. For example, the notions of cultural difference and multiculturalism can be considered semantically close to a certain extent. However, the cultural difference is seen as a second level node by the third researcher when multiculturalism is seen as a first level node by the first researcher. All researchers have organized their codes into two levels: first level codes are those displayed directly on the meaning units and codes of the second level include a set of first level codes.

Table 1 summarizes the results of individual researchers' codification. This is basically a summary of the number of first-level codes by hierarchical codes per researcher. Table 1 also shows that the second-level codes appear disjointed because the categories identified by a researcher are different from those considered by another. However, on closer examination, we found that the terms of the categories are similar. This point has been guided by the triangulation phase of our analysis process. Researchers have perfomed their analysis on the basis of triangulation level of operations. At the end of the analysis, to avoid any duplication researchers need to merge the same categories and rename some concepts that are synonymous. In triangulation, a third level has been added for better conceptualization of the problem. A point to be noted in this regards that as some nodes have become free as they could not be assigned to categories used by the researchers. This process of codification is consistent with recommendations issued by Krippendorff (1980), Patton (1990) and Tesch (1990). And, the result of the triangulation is given in the appendix.

Table 1. Synthesis of the results from the individual codification process

\begin{tabular}{|c|c|c|c|}
\hline $\begin{array}{ll}\text { Categories } & \text { Researcher(s) } \\
\end{array}$ & No. 01 & No. 02 & No. 03 \\
\hline External Characteristics & 03 & & \\
\hline Internal Characteristics & 05 & & \\
\hline Organizational Characteristics & 08 & & \\
\hline Personnality & 05 & & \\
\hline Behavior commitment & & 03 & \\
\hline Management of multicultural team & & 05 & \\
\hline Cultural Relatedness & & 07 & \\
\hline Conducive Environment & & 03 & \\
\hline Consciousness & & & 04 \\
\hline Organizational Culture & & & 06 \\
\hline Human Resource Management & & & 04 \\
\hline Heterogeneity in Race/Ethnicity/Nationality & & & 04 \\
\hline Higher career promotion & & & 03 \\
\hline Cultural Differences & & & 08 \\
\hline Consideration on Diversity & & & 07 \\
\hline Evaluation & & & 04 \\
\hline Leadership & & & 04 \\
\hline Education Programs & & & 02 \\
\hline Cost Advantages & & & 08 \\
\hline Creative advantages & & & 02 \\
\hline Resource Acquisition & & & 01 \\
\hline Marketing Advantages & & & 02 \\
\hline Inconclusive results & & & 03 \\
\hline
\end{tabular}


Table 2 provides a summary of the final coding. At this point we have noticed three distinct categories: the categories CDM (Cultural Diversity Management), WEC (Conducive Work Environment) and CA (Competitive Advantage).

The process of prioritization, we recall, is guided by our research question. Our goal is to study the impact of the management of cultural diversity on the competitive advantage of companies; and we have identified the success factors for managing diversity and competitiveness factors. It should also be noted that a third category has been identified; WEC class. We believe firm can achieve its competitive advantage by maintaining approapriate work environment through cultural diversity. Thus, we propose the following qualitative model to represent the relationship between the management of cultural diversity and the competitive advantage.

Table 2. Retained categories after the triangulation

\begin{tabular}{|c|c|c|}
\hline Categories & Sub-categories & Definition \\
\hline \multirow{5}{*}{$\begin{array}{l}\text { Cultural } \\
\text { Diversity } \\
\text { Management } \\
\text { (CDM) }\end{array}$} & Consciousness & $\begin{array}{l}\text { This subcategory includes the concepts that allow awareness of cultural } \\
\text { diversity within the organization. }\end{array}$ \\
\hline & $\begin{array}{l}\text { Internal } \\
\text { Dimensions }\end{array}$ & This subcategory includes the individual traits that cannot be changed \\
\hline & $\begin{array}{l}\text { External } \\
\text { Dimensions }\end{array}$ & $\begin{array}{l}\text { Unlike the internal dimensions, we focus here on individual } \\
\text { characteristics that can be changed by the effect of time, or contextual }\end{array}$ \\
\hline & Leadership & $\begin{array}{l}\text { At this level, we look at the factors that may influence the leadership of } \\
\text { the staff but also to actions that facilitate leadership development } \\
\text { through the management of cultural diversity. }\end{array}$ \\
\hline & $\begin{array}{l}\text { Organisational } \\
\text { Culture }\end{array}$ & $\begin{array}{l}\text { Here we grouped at the organizational level measures that promote the } \\
\text { emergence and development of cultural diversity. }\end{array}$ \\
\hline \multirow[t]{2}{*}{$\begin{array}{l}\text { Conducive Work } \\
\text { Environment } \\
\text { (CWE) }\end{array}$} & $\begin{array}{l}\text { Internal work } \\
\text { environment }\end{array}$ & $\begin{array}{l}\text { Considered intermediate variable between the management of cultural } \\
\text { diversity and competitive advantage, it is defined by the elements that } \\
\text { contribute to the establishment of a supportive work environment for the } \\
\text { management of cultural diversity in the development of the competitive } \\
\text { advantage of the company. }\end{array}$ \\
\hline & $\begin{array}{l}\text { Creativity \& } \\
\text { Innovation }\end{array}$ & $\begin{array}{l}\text { For creativity and innovation, we focus on factors of creativity and } \\
\text { innovation that contribute to competitive advantage and are related to } \\
\text { the management of cultural diversity. }\end{array}$ \\
\hline Competitive & Competences & It focuses primarily on factors that may influence the skills of staff. \\
\hline $\begin{array}{l}\text { Advantage } \\
\text { (CA) }\end{array}$ & Marketing & $\begin{array}{l}\text { This is to identify the elements highlighted by the management of } \\
\text { cultural diversity that are able to afford to have a positive view of other } \\
\text { cultures to better prepare and launch marketing activities of the } \\
\text { company. }\end{array}$ \\
\hline
\end{tabular}

The proposed model in Figure 1 reflects how the relationship between management of cultural diversity and competitive advantage is seen in the literature, particularly through the sample of articles that we used as a basis for understanding this problem. The exercise is to merge the codes and categories previously decontextualized into a comprehensive, intelligent and meaningful inside (Deschenaux, 2007). It appears, then, that the management model of cultural diversity (CDM) takes place through a process taking into account several key aspects. One of the fundamental prerequisites for better management of cultural diversity is to become aware, develop consciousness of the problematics of CDM for the leader and accepting the existence of cultural diversity. Therefore, it is necessary to promote the cultural diversity within the organization. Without the awareness of this proposition, we can not develop an integrated and effective management system of cultural diversity.

According to Gardenswartz and Lowe (1995), diversity can be understood as a scale at three levels: the internal dimensions, external dimensions and organizational dimensions. The internal dimensions are essentially within the person and are very much intrinsic (un-changeable). This denotes the age, gender, race, ethnicity, sexual 
orientation etc. The external dimensions, in turn, refer to religion, education, personal habits, experience, marital-parental status and so on. Last but not the least, organizational dimensions refer to the function of the individual in the organization, professional affiliation, its unity, division or department, its age, type of management and so on. Our study could also identify a set of factors that can be classified in terms of three dimensions (internal, external and organizational). For the sake of conformity to the logic of our model, factors within the organizational dimension confirming the level of the organizational culture (see Appendix).

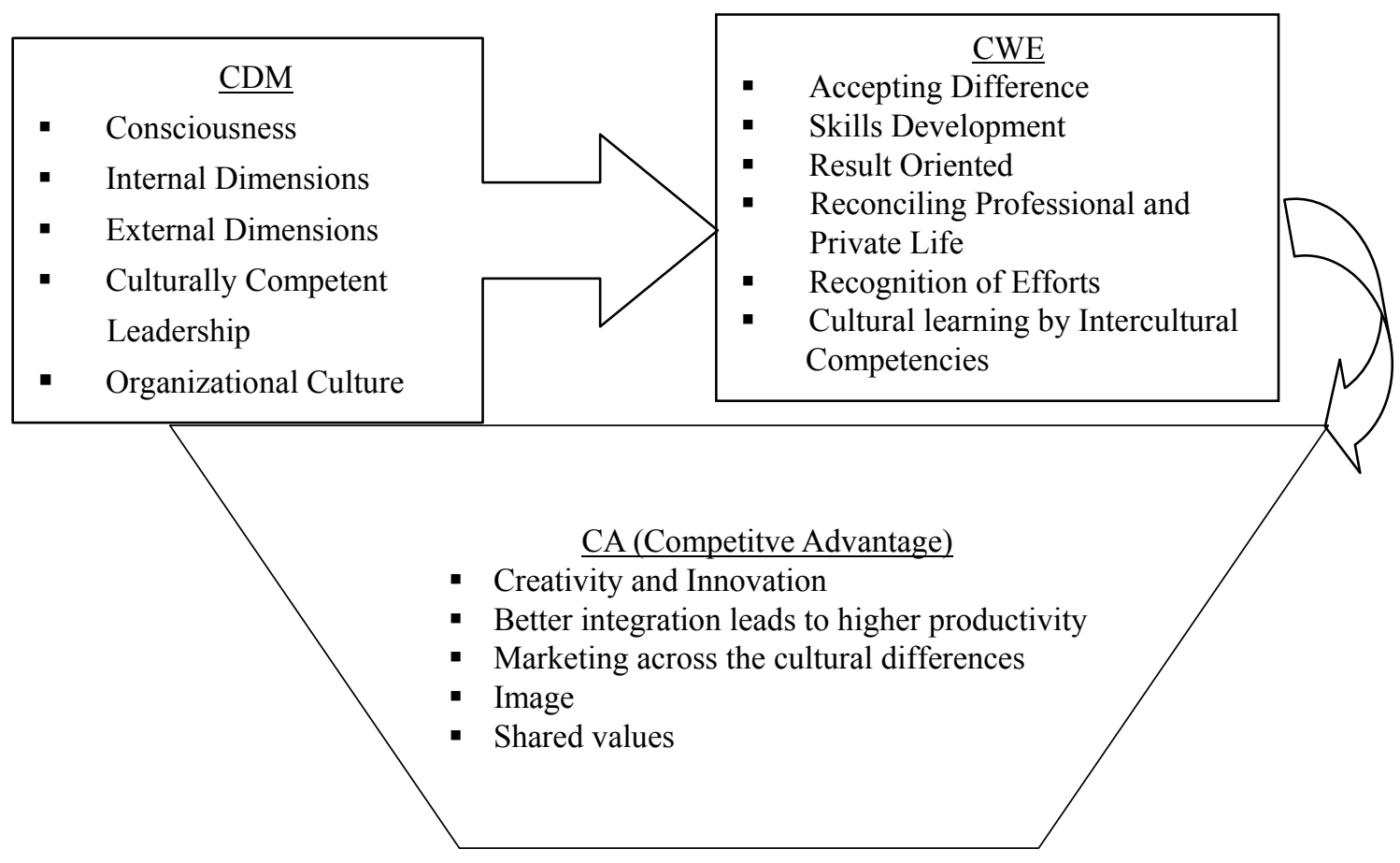

Figure 1. Explanatory model of relation between CDM and competitive advantage

However, this is not enough to become aware of the existence of cultural diversity in the workplace and to identify the various internal and external dimensions. Leadership is one of the leading determinants of the management of cultural diversity and it is also necessary to have a transformative leadership position to bring the seeds of cultural diversity which can provide a competitive advantage of the company. Leadership is the type of interpersonal influence by which an individual leads another individual or group to perform the task that he wants to lead to a positive term or end (Schermerhorn, Hunt, \& Osborn, 2002). His role is crucial in the management of cultural diversity in order to help mobilizing various actors around the pyramid to build the cultural diversity.

Leadership also plays pivital role in creating an organizational culture. Schein (1992) defines organizational culture as a set of basic assumptions, invented, discovered or developed by a group dealing problems with external adaptation and internal integration. This problems have largely been verified and to be considered and seen as valid and correct ways to think or behave so as to face the organizational problems. Organizational culture plays a dual role. In one hand, it refers to the external adaptation which comprises of the mission, core objectives, and means of the organization and on the other hand it refers to the internal adjustment that carries out through the collective mobilization and cohesion of the members of that organization. To address the problems associated with the group of cross-cultural differences, it may play a role in the management of cultural diversity by considering each particular culture as an asset to align the objectives and strategies of the organization. The task of integrating different cultures is primarily the noble task of the leader who is the ultimate architect and the builder of the organizational culture

Content analysis of our thirty scientific research articles denotes that the cross-cultural diversity management has a significant impact on achieving organizational effectivenss and competitive advantages which happens to be possible only in a 'Conductive Work Environment' (CWE). According to Hackman (1999) and Jackson, Joshi, and Erhardt (2003), the environment or context is the place where the teams, departments and organizations evolve (Hackman, 1999; quoted by Jackson et al., 2003). In other words, the organizational contexts include 
competitive strategy, patterns of social integration, social climate and organizational culture, and the history of diversity and so on (Jackson et al., 2003). As part of the management of cultural diversity, multiple devices can be set up to make the environment conducive. These include, among others, creating cultural synergies, intercultural cooperation and even the conditions for cultural learning (Loth, 2006). Moreover skills development of all employees, the balancing of public and privacy domains and the employee recognition are also a part of organizational context where cultural diversity is on practice (Chasserio \& Legault, 2009). These devices thus promote intercultural combination which is the basis for the management of cultural diversity.

From the literature review we came to know that few researchers have described in their articles about the notion of competitive advantage in multicultural organization. According to Chasserio \& Legault (2009), competitive advantage is measured in terms of individual creativity and innovation in the organization. In addition to that, Palich and Gomez-Mejia (1999), advocates the concept of "firm Efficiencies" as synonymous with competitive advantage. In all cases, the articles we have reviewed are full of notions and expressions which boost the intelligent concept of competitive advantage. As per Prahalad and Hamel (1990), marketing and skills are two key elements of competitive advantages. The core competent factors such as assets, capabilities, processes, information, knowledge, etc. are also seen as organizational resources (Barney, 1991; Al-Azad et. al., 2010) which allow the company to invent and carry out effective strategies. At this point it is worth stating that our model considers the management of cultural diversity as a process with a set of interrelated stages to create sustainable competitive advantages. And at this context, the evaluation of the management of cultural diversity is essential. Once the cultural diversity is on screen the evaluation can be done in an ex ante (upstream) way and continue to strive to manage it. It is, therefore, necessary to study the potential benefits of establishing a managerial and organizational system for managing cultural diversity. It is also necessary to study the potential barriers which may limit its effectiveness. The ex-post evaluation, in turn, would also reflect in our research if the targets are actually achieved which examines the differences between the agreed targets and outcomes.

\section{Summary and Conclusion}

The study has been conducted through content analysis by using the Nvivo software of a sample of thirty scientific papers. The objective was to study the influence of the management of cultural diversity on organizational effectiveness and competitive advantage of companies. At the end of the research we have identified five key dimentions of the cultural diversity to gain firms competitive advantages with creativity, innovation, Image and marketing, higher productivity and competences of work force in a systematic work environment. By addressing the competitive factors, findings of this research reveal that the management of cultural diversity can have a positive influence on factors like human capital, innovation capital and organization. Moreover, from the research outcome, we can say that marketing actions can also be identified through the management of cultural diversity which would reflect a positive impact on customer equity and capital investors. And from the research outcomes we can derive at a confirming conclusion that the establishment of a systematic cultural diversity management will lead to the firms' competitiveness.

Thus, we are confident that we have achieved our goals by examining the impact of cultural diversity on the competitive advantage with qualitative approach. After reviewing related artiles on the cultural diversity, we have derived at a conclusion that cultural diversity does have a significant impact on competitive advantage. However, to drive the research outcome into practice it requires awareness to break stereotype attitude towards cross-cultural work environment. It also requires a need to foster a long-term policy focusing communication, organizational culture, leadership influence and so on. Beyond all these aspects, a constant "social monitoring" practice in the work place is imperative to ensure day to day employee collaborative working environment for intellectual and socio-cultural development.

From the methodological point of view, reliability of content analysis refers to the tendency of researchers to recode the data in the same way as well as the tendency to classify the free nodes in the same categories. In this sense, the propose codification can be considered as reliable, as most of the researchers have identified free nodes and categories semantically similar or close. The validity of the study refers to the matching categories of the findings and transferability of results to a theory. The categories correspond to the results of research have shown that the effective management of cultural diversity contributes to the competitiveness of enterprises. The codification process can also be generalized as this follows the existing coding standards describing the classic manuals of Content analysis (Solomon, 1993; Weber, 1990; Krippendorf, 1980). However, it should be noted that this work could be enriched by integrating the process of analyzing the role of stakeholders in the management of cultural diversity within organizations.

It would have been an interesting task during the selection of sample articles to take into consideration of those 
articles that talk about the integrated government policies or international agreements to promote cultural diversity. At the same time, a larger number of articles might help to identify further the issue of cultural diversity and its links with the competitive advantage. The literature on this subject has grown considerably and we could enrich the study taking into account the current trends that are emerging in this particular area. In this study, it would also be interesting to include the concept of cultural proximity (Cultural relatedness) (Palich \& Gomez-Mejia, 1999).This issue could be explored by focusing the cultural proximity and the problems of integrating stakeholders and policy makers. Finally, we can conclude our study by stating the fact that our research had the merits to review most of the literature on the management of cultural diversity in relation to the competitive advantage and successfully sketch an explanatory model from a number of articles by bringing lights to the complex relationship between management of cultural diversity and competitive advantage.

\section{References}

Adler, N. J. (1994). Comportement organisationnel: une approche multiculturelle. Éditions Reynald Goulet, Université McGill, Canada.

Akinola, M., \& Thomas, D. A. (2006). Defining the attributes and processes that enhance the effectiveness of workforce diversity initiatives in knowledge intensive firms. Harvard Business School Working Paper, No. 07-019.

Al-Azad, M. S., Mohiuddin, M., \& Rashid, M. M. (2010). Knowledge Transfer in Offshore Outsourcing and International Joint Ventures (IJVs): A Critical Literature Review from Cross-Cultural Context. Global Journal of Strategies and Governance, 1(1), 41-67.

Barney, J. B. (1991). Firm resources and sustained competitive advantage. Journal of Management, 17(1), 99-120. http://dx.doi.org/10.1177/014920639101700108

Bryan, J. H. (1999). The diversity imperative. Executive Excellence, p. 6.

Carrell, M. R., \& Everett, E. M. (1995). Defining workforce diversity in public sector organizations. Public Personnel Management, 24(1), 99-117.

Côté, M. (2006). Intégration des immigrants sur le marché du travail québécois. Essai de maîtrise, Université Laval, p. 67.

Cox, T., \& Blake, S. (1991). Managing cultural diversity: implications for organizational competitiveness. The Executive Academy of Management, 5(3), 45-56. http://dx.doi.org/10.5465/AME.1991.4274465

Cox, T. \& Beale, R. L. (1997). Developing competency to manage diversity. San Francisco, California, USA: Berrett-Koehler.

Cox, T. (1993). Cultural diversity in organizations: theory, research, and practice. San Francisco, California, USA: Berrett-Koehler.

D’Iribarne, P. (1998). Culture et mondialisation, collection "la couleur des idées". Éditions du seuil.

Dass, P., \& Parker, B. (1993). Strategies for managing human resource diversity: From resistance to learning Parshotam. The Academy of Management Executive, 13(2), 68-80.

Deschenaux, F. (2007). Guide d'introduction au logiciel. QSR NVivo 7, Association pour la recherche qualitative, p. 32.

Downe-Wamboldt, B. (1992). Content analysis: method, applications, and issues. Health Care for Women International, 13(1), 313-321. http://dx.doi.org/10.1080/07399339209516006

Gardenswartz, L., \& Rowe, A. (1995). Diverse teams at work. New York: Irwin.

Gilbert, J. A., Stead, B. A., \& Ivancevich, J. (1999). Diversity management: A new organizational paradigm. Journal of Business Ethics, 21(1), 61-76. http://dx.doi.org/10.1023/A:1005907602028

Hall, E. T. (1959). The silent language, Anchor Press, Double day. New York.

Hall, E. T. (1960). The silent language of overseas business. Harvard Business Review, 38(3), 87-95.

He, R., \& Liu, J. (2010). Barriers of Cross Cultural Communication in Multinational Firms: A Case Study of Swedish Company and its Subsidiary in China. Retrieved from http://hh.diva-portal.org/smash/get/diva2:344618/FULLTEXT01

Hofstede, G. (1980). Culture's Consequences: International Differences in Work-related Values. Beverly Hills, CA: Sage Publication Inc. 
Hofstede, G. (2001). Culture's consequences: comparing values, behaviors, institutions, and organizations across nations (p. 475). Beverly Hills: Sage Publications.

Hsieh, H. F., \& Shannon, S. E. (2005). Three approaches to qualitative content analysis. Qual Health Res., 15(9), 1277-1288. http://dx.doi.org/10.1177/1049732305276687

Jackson, S. E., \& Ruderman, M. N. (1995). Diversity in workteams: research paradigms for a changing workplace. Washington, D.C.: American Psychological Association. http://dx.doi.org/10.1037/10189-000

Jackson, S. E., Joshi, A., \& Erhardt, N. L. (2003). Recent research on team and organisation diversity: SWOT analysis and implications. Journal of Management, 29(6), 801-830. http://dx.doi.org/10.1016/S0149-2063_03_00080-1

Jain, H., \& Verma, A. (1996). Managing workforce diversity for competitiveness: The Canadian Experience. International Journal of Manpower, 17(4/5), 14-29. http://dx.doi.org/10.1108/01437729610127677

Krippendorff, K. (1980). Content analysis: An introduction to its methodology. Beverly Hills: Sage publication.

Lawrence, P. R., \& Lorsch, J. W. (1967). Organisation and environment: Managing differentiation and integration. Homewood, Illinois, USA: Irwin.

Legault, M. J., \& Chasserio, S. (2009). Strategic human resssources management is irrelevant when it comes to highly skills professionals in the new economy. Retrieved from http://www.archipel.uqam.ca/1379/1/IJHRM-Fin.pdf

Leung, A. K. Y., Maddux, W. W., Galinsky, A. D., \& Chi-yue, C. (2008). Multicultural experience enhances creativity: The when and how. American Psychologist, 63(3), 169-181. http://dx.doi.org/10.1037/0003-066X.63.3.169

Loth, D. (2006). Les enjeux de la diversité culturelle: le cas du management des équipes interculturelles'. Revue Internationale sur le Travail et la Société, 4(2), 124-133.

Michael, M., \& Hofstede, G. (2011). The evolution of Hofstede's doctrine. Cross Cultural Management: An International Journal, 18(1), 10-20. http://dx.doi.org/10.1108/13527601111104269

Milliken, F. J., \& Martins, L. L. (1996). Searching for common threads: Understanding the multiple effects of diversity in organizational groups. Academy of Management Review, 21(1), 402-433. http://dx.doi.org/10.2307/258667

Mohiuddin, M., Sidi Mahmoud, A. M., Samim Al-A., \& Diouf, D. (2009). Étude Qualitatif de la gestion de la diversité culturelle sur l'avantage compétitf des enterprises' (Qualitative study of the impact of cultural diversity on competitive advantages of firms). Journal of Global Business Administration, 1(1).

Nkomo, S. M., \& Cox, Jr. (1996). Diverse Identities in Organizations. In S. Clegg, C. hardy and W. Nord (Eds.), Handbook of Organization Studies (pp. 338-356). London, England: Sage Publications.

Palich, L. E., \& Gomez-Mejia, L. R. (1999). A theory of global startegy end firm efficiencies: considering the effects of cultural diversity. Journal of management, 25(4), 587-606. http://dx.doi.org/10.1177/014920639902500406

Patton, M. Q. (1990). Qualitative evaluation and research methods (2nd ed.). Newbury Park, CA: Sage Publications Inc.

Polzer, J. T., Milton, P. L., \& Swann, W. B. (2000). Capitalizing on diversity: Interpersonal congruence in small work groups. Administrative Science Quarterly, 47(2), 296-324. http://dx.doi.org/10.2307/3094807

Reddy, A. (2011). Cultural dimensions \& impact on performance management. Zenith: International Journal of Multidisciplinary Research, 1(6), 300-311.

Schein, E. (1992). Organisational culture and leadership (2nd ed.). Jossey Bass, California.

Schermerhorn, J. R., Hunt, J. G., \& Osborn, R. N. (2002). Comportement humain et organisation (2nd ed.). Village Mondial.

Seymen, O. A. (2006). The cultural diversity phenomenon in organizations and different approaches for effective cultural diversity management: a literary review. Cross Cultural Management: An International Journal, 13(4), 296-315. http://dx.doi.org/10.1108/13527600610713404

Solomon, M. (1993). Content analysis: a potent tool in the searcher's arsenal. Database, 16(2), 62-67.

Taylor, C. L. (1995). Dimensions of diversity in canadian business: Building a business case for valuing ethno 
cultural diversity. The Conference Board of Canada, Ottawa, Canada.

Tesch, F. R. (1990). Qualitative research: Analysis types and software tools. Bristol, PA: Falmer Press.

Théry, B. (2002). Manager dans la diversité culturelle. Éditions d'Organisation, Paris, p. 249.

Thornhill, A., Lewis, P., Millmore, M., \& Saunders, M. (2000). Managing change. A human resource strategy approach. Harlow: Prentice Hall.

Torres, C., \& Bruxelles, M. (1992). Capitalizing on global diversity. HR Magazine, pp. 30-39.

Trompenaars, F. (1993). L'entreprise multiculturelle. Éditions Maxima.

Van Dijk, T. A. (1977). Text and context: explorations in the semantics and pragmatics of discourse. London, New York: Longman.

Watson, W. E., Kannales, K., \& Michaelsen, L. K. (1993). Cultural diversity's impact on interaction process and performance: Comparing homogeneous and diverse task groups. Academy of Management Journal, 36(1), 590-602. http://dx.doi.org/10.2307/256593

Weber, R. P. (1990). Basic content analysis (2nd ed.). Newbury Park, CA: Sage publication.

White R. D. (1999). Managing the diverse organization: the imperative for a new multicultural paradigm. Public Administration \& Management: An Interactive Journal, 4(4), 469-493.

Williams K., \& O’Reilly, C. A. (1998). Demography and diversity: A review of 40 years of research. In B. Staw and R. Sutton (Eds.), Research in Organizational Behavior Greenwich. CT: JAI Press.

Yingying, Z., \& Lopez-Pascual, J. (2012). Dynamic versus static culture in international business: a study of Spanish banking in China. Cross Cultural Management: An International Journal, 19(4), 588-611. http://dx.doi.org/10.1108/13527601211270039

\section{Appendix}

Appendix 1. Codification by Researchers

Researcher 1

\begin{tabular}{ll}
\hline Categories & Freenodes \\
\hline External & Multi-linguism \& Openness to Multi-linguism \\
Characteristics & Spontaneity \\
Internal & Racial Diversity \\
Characteristics & Imagination \\
& Cultural Intelligence \\
& Joy and Pride of Living \\
& Positive Thinking \\
& Collaboration \& Conflicts \\
Organizational & Ethnic Diversity \& Multi-culturalism \\
Characteristics & Exchange \\
& Organizational Environment \\
& Multicultural Practices and Capacities \\
& Stigmatisation \\
& Age \\
& Idea Generation \\
& Independent \& Motivation \\
& Intrinsic Objective \\
& Openness of Spirit \\
\hline
\end{tabular}


Researcher 2

\begin{tabular}{ll}
\hline \multicolumn{1}{c}{ Categories } & \multicolumn{1}{c}{ Free Nodes } \\
\hline Behaviour & Overtime \\
Commitment & Customer Focus \\
& Constant Availability \\
Managing & Cultural Synergies \\
multi-cultural & Inter-cultural Cooperation \\
teams & Understaning of Sense \\
& Inter-cultural Learning by the Intercultural Competence \\
Cultural & Technology-Related Efficiencies \\
Relatedness & Shared Managerial Cognitions \\
& Production- Related Efficiencies \\
& Market- Related Efficiencies \\
& Efficient Strategy Implementation \\
& Efficient Strategy Formulation \\
& Efficient Strategy Control \\
& Skills Development \\
& Reconciling Professional Life and Private Life \\
& Recognition of Effort \\
\hline
\end{tabular}

Researcher 3

\begin{tabular}{|c|c|c|}
\hline Categories & Sub-Categories & Free-nodes \\
\hline \multirow{20}{*}{$\begin{array}{l}\text { Cultural } \\
\text { Diversity } \\
\text { Management }\end{array}$} & \multirow{4}{*}{ Consciousness } & Perception \\
\hline & & Investments \\
\hline & & Importance \\
\hline & & Awareness \\
\hline & \multirow{6}{*}{$\begin{array}{l}\text { Organizational } \\
\text { Culture }\end{array}$} & Understanding \\
\hline & & Stakeholder \\
\hline & & Socialization \\
\hline & & Missions \\
\hline & & Integrated Action \\
\hline & & Firm Level Culture \\
\hline & \multirow{4}{*}{$\begin{array}{l}\text { Human } \\
\text { Resource } \\
\text { Management }\end{array}$} & Skills Shortage \\
\hline & & Investment (Non-financial) \\
\hline & & Focused Policies \\
\hline & & Domino Effects \\
\hline & \multirow{4}{*}{$\begin{array}{l}\text { Heterogeneity in } \\
\text { Race/Ethnicity/ } \\
\text { Nationality }\end{array}$} & Goals \\
\hline & & Ethnic Diversity \\
\hline & & Diversity \\
\hline & & Disadvantage \\
\hline & \multirow{2}{*}{$\begin{array}{l}\text { Higher Career } \\
\text { Promotion }\end{array}$} & Favorable Policies \& Openness \\
\hline & & Persistant Difficulties \\
\hline
\end{tabular}




\begin{tabular}{|c|c|c|}
\hline \multirow{25}{*}{$\begin{array}{l}\text { Cultural } \\
\text { Diversity } \\
\text { Management }\end{array}$} & \multirow{8}{*}{$\begin{array}{l}\text { Cultural } \\
\text { Differences }\end{array}$} & Personal Traits \\
\hline & & Organizational Barriers \\
\hline & & Language \\
\hline & & Initiatives \\
\hline & & Cultural Traits \\
\hline & & Cultural Norms \\
\hline & & Critical Thinking \\
\hline & & Behavior \\
\hline & \multirow{7}{*}{$\begin{array}{l}\text { Consideration on } \\
\text { Diversity }\end{array}$} & Values \\
\hline & & Urgency \\
\hline & & Culture \\
\hline & & Constraints \\
\hline & & Collective Actions \\
\hline & & Challenges \\
\hline & & Biases \\
\hline & \multirow{4}{*}{ Evaluation } & Policy Evaluation \\
\hline & & Overseeing \\
\hline & & Cultural Audits \\
\hline & & Coherence \\
\hline & \multirow{4}{*}{ Leadership } & Top Management \\
\hline & & Organizational Supports \\
\hline & & Determination \\
\hline & & Coordinated Efforts \\
\hline & Education & Training \\
\hline & Programs & Skills Shortage \\
\hline \multirow{15}{*}{$\begin{array}{l}\text { Competitive } \\
\text { Advantages }\end{array}$} & \multirow{7}{*}{$\begin{array}{l}\text { Cost } \\
\text { Advantages }\end{array}$} & Values \\
\hline & & Savings and Improvements \\
\hline & & Process \\
\hline & & Pro-active \\
\hline & & Policy \\
\hline & & Cost \\
\hline & & Benefits \\
\hline & \multirow{2}{*}{$\begin{array}{l}\text { Creative } \\
\text { Advantages }\end{array}$} & Multiculturalism \\
\hline & & Core Competencies \\
\hline & $\begin{array}{l}\text { Resource } \\
\text { Acquisition }\end{array}$ & Long Term Vision \\
\hline & \multirow{2}{*}{$\begin{array}{l}\text { Marketing } \\
\text { Advantages }\end{array}$} & Performance \\
\hline & & Business Case \\
\hline & \multirow{3}{*}{$\begin{array}{l}\text { Inconclusive } \\
\text { Results }\end{array}$} & Research Gap \\
\hline & & Undetermined Results \\
\hline & & Incomplete Research \\
\hline
\end{tabular}

Appendix 2. Codification Post-Triangulation 
Appendix 2a. Post-Triangulation codification selected

\begin{tabular}{|c|c|c|}
\hline Categories & Sub-categories & Free Nodes \\
\hline \multirow{44}{*}{$\begin{array}{l}\text { Cultural } \\
\text { Diversity } \\
\text { Management } \\
\text { (CDM) }\end{array}$} & \multirow{4}{*}{ Conscience } & Perception \\
\hline & & Investments \\
\hline & & Importance \\
\hline & & Awareness \\
\hline & \multirow{7}{*}{$\begin{array}{l}\text { Internal } \\
\text { Dimensions }\end{array}$} & Racial Diversity \\
\hline & & Positive Thinking \\
\hline & & Personal Traits \\
\hline & & Language \\
\hline & & Cultural Traits \\
\hline & & Cultural Norms \\
\hline & & Ethnic Diversity \\
\hline & \multirow{8}{*}{$\begin{array}{l}\text { External } \\
\text { Dimensions }\end{array}$} & Critical Thinking \\
\hline & & Behavior \\
\hline & & Multilinguism \\
\hline & & Open to Mutilinguism \\
\hline & & Values \\
\hline & & Culture \\
\hline & & Constant Availability \\
\hline & & Openness of Spirit \\
\hline & & Collaboration \\
\hline & & Conflicts \\
\hline & & Organizational Environnement \\
\hline & & $\begin{array}{l}\text { Multicultural Capability and } \\
\text { Practices. }\end{array}$ \\
\hline & & Multiculturalisme \\
\hline & & Stigmatisation \\
\hline & & Culturals \\
\hline & & Inter-cultural Coopération \\
\hline & & Understaning Sounds Systems \\
\hline & Organizational & Favorable Policies \\
\hline & & Openness \\
\hline & & Persistant Difficulties \\
\hline & & Organizational Barriers \\
\hline & & Collective Action \\
\hline & & Understanding \\
\hline & & Stakeholder \\
\hline & & Socialization \\
\hline & & Missions \\
\hline & & Integrated Action \\
\hline & & Firm Level Culture \\
\hline & & Top Management \\
\hline & J eaderchin & Organizational Supports \\
\hline & Lequetsinp & Determination \\
\hline & & Coordinated Efforts \\
\hline & & Skills Development \\
\hline
\end{tabular}




\begin{tabular}{lll}
\hline Conducive Work & & Reconciling Professional Life \\
Environment & and Private Life \\
(CWE ) & Recognition of Effort \\
& Intercultural Learninng by the \\
& Inter-cultural Competence \\
& Joy and Living Happiness \\
& Training \\
& & Skills Shortage \\
\hline & Innovation \& & Imagination \\
& Creativity & Initiative \\
& & Pro-active \\
& Competences & Skills Shortage \\
& & Investment (Non-financial) \\
& & Focused Policies \\
& & Domino Effects \\
& & Core Competencies \\
Competitive & & Long Terme Vision \\
Advantage (CA) & & Values \\
& & Savings and Improvements \\
& & Process \\
& Cost & Pro-active \\
& Advantages & Policy \\
& & Cost \\
& & Benefits \\
& & Performance \\
& &
\end{tabular}

Appendix 2b. Post-Triangulation remaining free nodes

\begin{tabular}{ll}
\hline Age & Idea Generation \\
\hline Independence and Motivation & Intrinsic Objectives \\
Policy Evaluation & Challenges \\
Overseeing & Biaises \\
Cultural Audit & Coherence \\
Shared Managerial Cognitions & \\
Production-Related Efficiencies & Technology-Related Efficiencies \\
Market-Related Efficiencies & Efficient Strategy Control \\
Efficient Strategy Implementation & Efficient Strategy Formulation \\
\hline
\end{tabular}

